\title{
Differentiation of human adipose-derived stem cells towards cardiomyocytes is facilitated by laminin
}

\author{
A. van Dijk • H. W. M. Niessen • B. Zandieh Doulabi • \\ F. C. Visser • F. J. van Milligen
}

Received: 14 March 2008 / Accepted: 25 September 2008 / Published online: 7 November 2008

(C) The Author(s) 2008. This article is published with open access at Springerlink.com

\begin{abstract}
Adipose-derived stem cells (ASCs) are promising candidates for therapy in myocardial infarction (MI). However, the frequency of human ASCs that differentiate towards cardiomyocytes is low. We hypothesized that adherence to extracellular matrix molecules that are upregulated after MI might increase human stem cell

This study was supported by the Institute for Cardiovascular Research of the VU Medical Centre in Amsterdam, The Netherlands (ICaR-VU), project 200380.
\end{abstract}

A. van Dijk · H. W. M. Niessen · F. J. van Milligen Department of Pathology, VU University Medical Centre, Amsterdam, The Netherlands

H. W. M. Niessen

Department of Cardiac Surgery, VU University Medical Centre, Amsterdam, The Netherlands

\section{F. C. Visser}

Department of Cardiology, VU University Medical Centre,

Amsterdam, The Netherlands

B. Zandieh Doulabi

Department of Orthopaedics, VU University Medical Centre, Amsterdam, The Netherlands

A. van Dijk · H. W. M. Niessen - F. C. Visser

ICaR-VU, Institute of Cardiovascular Research,

VU University Medical Centre,

Amsterdam, The Netherlands

B. Zandieh Doulabi

STEGA, Skeletal Tissue Engineering Group Amsterdam,

Amsterdam, The Netherlands

A. van Dijk $(\bowtie)$

ICaR-VU, Department of Pathology,

VU University Medical Centre,

De Boelelaan 1117,

1081 HV Amsterdam, The Netherlands

e-mail: Annemieke.vandijk@vumc.nl differentiation towards cardiomyocytes. We analysed putative ASC differentiation on fibronectin-coated, laminincoated and uncoated culture plates. Expression of cardiac markers in cells was analysed 1, 3 and 5 weeks after stimulation with 5-aza-2-deoxycytidine. After 1 week, mRNA expression of myosin light chain- $2 \alpha$ (MLC-2 $\alpha$ ), an early marker in cardiomyocyte development, was increased significantly in treated cells, independent of coating. At 5 weeks, however, mRNA expression of the late cardiomyocyte development marker SERCA $2 \alpha$ was only significantly increased in 5-aza-2-deoxycytidine-treated cells cultured on laminin. Significantly higher numbers of cells were immunopositive for MLC- $2 \alpha$ in cultures of treated cells grown on laminin-coated wells, when compared with cultures of treated cells grown on uncoated wells, both at 1 week and at 5 weeks. Furthermore, after 3 weeks, significantly more $\alpha$-actinin- and desmin-positive cells were detected after treatment with 5-aza-2-deoxycytidine, but only in uncoated wells. After 5 weeks, however, the number of desmin-positive cells was only significantly increased after treatment of cells with 5-aza-2-deoxycytidine and culture on laminin ( $61 \%$ positive cells). Thus, we have found that a high percentage of human ASCs can be differentiated towards cardiomyocytes; this effect can be improved by laminin, especially during late differentiation.

Keywords Adipose $\cdot$ Stem cells $\cdot$ Differentiation .

Extracellular matrix $\cdot$ Laminin $\cdot$ Human

\section{Introduction}

Cardiovascular diseases are a leading cause of morbidity and mortality in the western world (Wang and Sjoquist 2006), with heart failure resulting from myocardial infarc- 
tion (MI) being the most common aetiology (Lu et al. 2004). Heart failure is partly caused by the loss of cardiomyocytes and the limited capacity of spontaneous regeneration of the heart. This results in replacement of injured myocardium by scar tissue, which adversely affects cardiac function (Smits et al. 2005; Wang and Sjoquist 2006).

A promising tool for the restoration of contractile function after MI is stem cell therapy. In comparison with current therapies that focus on the restoration of the blood flow, stem cells not only might improve neovascularization, but also might replace lost cardiomyocytes, since they have the capacity to differentiate into cardiomyocytes (Wang and Sjoquist 2006; Orlic et al. 2001; Strauer et al. 2002). However, effectively to restore contractile function of the heart after MI, sufficient stem cells need to attach to the infarcted area and subsequently differentiate into cardiomyocytes, thereby replacing a substantial fraction of the lost cardiomyocytes. Unfortunately, recent studies suggest that only a small portion of stem cells applied to the heart invade the infarcted area and ultimately differentiate into cardiomyocytes (Lee et al. 2007).

Several factors might influence the fate of the stem cells in the heart. One of these is the source of stem cells used. Although various cell sources have been used experimentally for stem cell transplantation after MI, the optimal choice of stem cell source remains controversial (Zhang et al. 2007). A potential source of stem cells for transplantation is adipose tissue. Adipose-tissue-derived stem cells (ASCs) are of mesenchymal origin, can easily be harvested in large quantities, show high proliferation rates in culture and have the capacity to differentiate towards several cell types, including cardiomyocytes (Rangappa et al. 2003; Oedayrajsingh-Varma et al. 2006).

Several studies have shown the differentiation of animal ASCs towards cardiomyocytes after treatment with chemical substances such as 5-azacytidin. Spontaneous differentiation of ASCs towards cardiomyocytes has also been described (Planat-Benard et al. 2004; Rangappa et al. 2003; Bai et al. 2007). Furthermore, in vivo animal studies, in which ASCs have been transplanted after MI, have also shown the differentiation of ASCs towards cardiomyocytes and increased cardiac function (Strem et al. 2005; Zhang et al. 2007). However, studies on human ASCs are limited, and only low percentages $(<2 \%)$ of spontaneous differentiation have been described (Bai et al. 2007; Song et al. 2007). Only Gaustad et al. (2004) have described a higher differentiation rate $(25 \%$ desmin-positive cells) of human ASCs in vitro, but only in one donor and only after the cells had been permeabilized and exposed to extracts of rat cardiomyocytes. Before the translation of human ASCs to a clinical setting, we therefore need to show that a significant number of such cells can differentiate into cardiomyocytes.

Another important factor for stem cell adherence and differentiation is the timepoint of transplantation after MI
(Lu et al. 2004). Homing, growth and differentiation of stem cells after MI is known to depend on the environment in the heart, and especially on the adhesion factors at the site of injury, all of which change dramatically after MI ( $\mathrm{Lu}$ et al. 2004; Malek et al. 2006; Wang and Sjoquist 2006; Chastain et al. 2006; Salasznyk et al. 2004). Therefore, stem cell therapy has to be applied at the moment after infarction when the environment is most favourable for stem cell adhesion and cardiomyocyte formation. Two extracellular matrix (ECM) molecules of human mesenchymal stem cells are important for stem cell survival and differentiation towards other lineages: laminin and fibronectin (Hashimoto et al. 2006; Salasznyk et al. 2004; Wijelath et al. 2004). Both these proteins are expressed in the normal heart and increase after MI (Froen and Larsen 1995; Knowlton et al. 1992; Willems et al. 1996). In vivo, an effect of these ECM molecules on stem cell survival and differentiation can be expected if stem cell therapy is applied once these proteins have accumulated. In a previous study, we have shown that ASCs attach best to fibronectin in comparison with other ECM molecules; we have also demonstrated that fibronectin is increased from $12 \mathrm{~h}$ onwards after MI in the human heart (van Dijk et al. 2008). Further, laminin is described to increase from 3 days post-MI (Morishita et al. 1996).

Our ultimate goal is to optimize stem cell transplantation by directing a larger number of stem cells to the infarction site and by stimulating stem cell differentiation in vivo. In this study, we have therefore investigated the effect of fibronectin and laminin on the putative differentiation of human ASCs towards cardiomyocytes.

\section{Materials and methods}

\section{Adipose tissue donors}

Human subcutaneous adipose tissue samples were obtained as waste material after elective surgery and donated after informed consent of the patients from various clinics in Amsterdam, The Netherlands. This study complied with the principles of the Declaration of Helsinki. Adipose tissue was harvested from the abdomen or hip and thigh region by using either resection or tumescent liposuction. Seven healthy non-obese female donors (age range: 33-51 years) were included in this study.

Isolation of stromal vascular fraction of adipose tissue

Adipose tissue was stored in sterile phosphate-buffered saline (PBS; Braun, Melsungen, USA) at $4^{\circ} \mathrm{C}$ and processed within $24 \mathrm{~h}$ after surgery as described previously (Oedayrajsingh-Varma et al. 2006). In brief, resected 
material was minced by using a surgical scalpel before being processed. After extensive washes with PBS, the ECM was enzymatically digested with $0.1 \%$ collagenase A (Roche Diagnostics, Mannheim, Germany) in PBS containing $1 \%$ bovine serum albumin (BSA; Roche Diagnostics) under intermittent shaking for $45 \mathrm{~min}$ at $37^{\circ} \mathrm{C}$. Then, the material was washed with Dulbecco's modified Eagle's medium (DMEM-glucose; BioWhittaker, Cambrex, Verviers, Belgium) containing $10 \%$ fetal bovine serum (FBS; HyClone, South Logan, Utah, USA) and centrifuged for $10 \mathrm{~min}$ at $600 \mathrm{~g}$. The cell pellet was resuspended in PBS and passed through a $200-\mu \mathrm{m}$ mesh (Braun/Beldico, Marche-en-Famenne, Belgium) to obtain a single-cell suspension. To remove contaminating erythrocytes, the cells were subjected to Ficoll density centrifugation (lymphoprep, $\rho=1.077 \mathrm{~g} / \mathrm{ml}$, osmolarity $280 \pm 15 \mathrm{mOsm}$; Axis-Shield, Oslo, Norway). The cell-containing interface was harvested and washed with DMEM containing 10\% FBS. Cells were frozen under "controlled rate" conditions and stored in liquid nitrogen until needed in experiments.

\section{Cell culture}

Cells from the stromal vascular fraction were seeded at $1 \times 10^{5}$ cells $/ \mathrm{cm}^{2}$ and cultured for several passages in DMEM supplemented with $10 \% \mathrm{FBS}, 100 \mathrm{U} / \mathrm{ml}$ penicillin, $100 \mu \mathrm{g} / \mathrm{ml}$ streptomycin, $2 \mathrm{mM} \mathrm{L}$-glutamine (all from Gibco, Invitrogen, Calif., USA; normal culture medium), in a humidified atmosphere of $5 \% \mathrm{CO}_{2}$ at $37^{\circ} \mathrm{C}$. Media were changed twice a week. Once $80 \%-90 \%$ confluency has been reached, cells were detached with $0.5 \mathrm{mM}$ EDTA/ $0.05 \%$ trypsin (Gibco), for $5 \mathrm{~min}$ at $37^{\circ} \mathrm{C}$, and replated.

To assess ASC differentiation towards cardiomyocytes, culture-expanded cells (p3) were plated into 6-well culture dishes at a density of 50,000 cells per well, each well having been coated with $2.5 \mu \mathrm{g} / \mathrm{cm}$ fibronectin (Roche) or $0.12 \mu \mathrm{g} / \mathrm{cm}$ laminin (Roche) or left uncoated, in normal culture medium. The cells were then cultured in DMEM containing $15 \%$ FBS and, when $50-60 \%$ confluent, stimulated with 5-aza-2-deoxycytidine $(9 \mu \mathrm{M}$; Fluka, Sigma Aldrich, St. Louis, Mo. USA) for $24 \mathrm{~h}$ in DMEM supplemented with $15 \% \mathrm{FBS}, 100 \mathrm{U} / \mathrm{ml}$ penicillin, $100 \mu \mathrm{g} / \mathrm{ml}$ streptomycin, $2 \mathrm{mM}$ L-glutamine and 1\% ITS + premix (BD Biosciences, Bedford, Mass., USA). This concentration of 5-aza-deoxycytidine has been shown to induce differentiation of rabbit ASCs towards cardiomyocytes on uncoated culture plates (Rangappa et al. 2003). Cells were harvested after 1, 3 and 5 weeks.

Reverse transcription with polymerase chain reaction

Cells were harvested in $750 \mu \mathrm{l}$ TRIzol reagent (Invitrogen) per well (10 min, room temperature), after 1 and 5 weeks.
Total RNA from the cells was isolated by incubating the samples in $150 \mu \mathrm{l}$ chloroform for $2 \mathrm{~min}$ after vigourous shaking. Samples were centrifuged for $15 \mathrm{~min}$ at $12,000 \mathrm{~g}$ and the upper water phase was transferred to a new tube containing $5 \mu \mathrm{l}$ glycogen $(1 \mu \mathrm{g} / \mu \mathrm{l})$ and $375 \mu \mathrm{l}$ isopropyl. After a 10-min incubation at room temperature, the cells were centrifuged for $10 \mathrm{~min}$ at $12,000 \mathrm{~g}$ and the pellet was washed with $1 \mathrm{ml} 75 \%$ ethanol. The samples were centrifuged again for $5 \mathrm{~min}$ at $7500 \mathrm{~g}$ and, when the RNApellet was dried, it was taken up in RNAse-free water.

cDNA synthesis (GeneAmp PCR System9700, PE Applied Biosystems, Calif., USA) was performed by using $0.5-1 \mathrm{mg}$ total RNA in a $20-\mathrm{ml}$ reaction mix containing $5 \mathrm{U}$ Transcriptor Reverse Transcriptase (Roche), 0.08 A260 U random primers (Roche), $1 \mathrm{mM}$ each dNTP (Invitrogen), RNAse inhibitor, and $1 \times$ concentrated Transcriptor reverse transcription (RT) reaction buffer. The cDNA was stored at $-80^{\circ} \mathrm{C}$ prior to real-time polymerase chain reaction (PCR).

Real-time PCRs were performed by using the SYBRGreen reaction kit according to the manufacturer's instructions (Roche) in a LightCycler 480 (Roche). cDNA ( 5 ng) was used in a volume of $20 \mu \mathrm{l}$ PCR mix (LightCycler DNA Master Fast start plus Kit, Roche) containing a final concentration of 0.5 pmol primers. Relative housekeeping gene expression (18S) and relative target gene expression (cardiac-specific SERCA $2 \alpha$, myosin light chain- $\alpha$ [MLC$2 \alpha$, desmin and $\alpha$-actinin) were determined.

Primers (Invitrogen) used for real-time PCR are listed in Table 1. They were designed by using Clone Manager Suite software program version 6 (Scientific \& Educational Software, Cary, N.C., USA). The amplified PCR fragment extended over at least one exon border, based on homology in conserved domains between human, mouse, rat, dog and cow, except for the $18 \mathrm{~S}$ gene, which is encoded by one exon only.

PCR conditions were as follows: for $18 \mathrm{~S}$, a 1-min preincubation at $95^{\circ} \mathrm{C}$, followed by 30 cycles of amplification at $95^{\circ} \mathrm{C}$ for $5 \mathrm{~s}, 56^{\circ} \mathrm{C}$ for $10 \mathrm{~s}, 72^{\circ} \mathrm{C}$ for $15 \mathrm{~s}$, and $82^{\circ} \mathrm{C}$ for $5 \mathrm{~s}$, followed by melting curve analysis; for MLC- $2 \alpha$, SERCA, desmin and $\alpha$-actinin, a 10 -min pre-incubation at $95^{\circ} \mathrm{C}$, followed by 45 cycles of amplification at $95^{\circ} \mathrm{C}$ for $5 \mathrm{~s}, 58^{\circ} \mathrm{C}$ for $5 \mathrm{~s}, 72^{\circ} \mathrm{C}$ for $15 \mathrm{~s}$, and $82^{\circ} \mathrm{C}$ for $5 \mathrm{~s}$ followed by melting curve analysis.

Quantification was carried out by normalizing the values of relative target gene expression to relative housekeeping gene (18S) expression. Amplified PCR products were electrophoresed on a $1.6 \%$ agarose gel containing $0.5 \mu \mathrm{g} / \mathrm{ml}$ ethidium bromide.

Immunological staining

Cells were trypsinized after 3 and 5 weeks. Cytospin slides were prepared by spinning $10^{4}$ ASCs for $5 \mathrm{~min}$ at $500 \mathrm{rpm}$ 
Table 1 PCR primers and PCR conditions

\begin{tabular}{|c|c|c|c|}
\hline \multirow[t]{2}{*}{ Gene } & \multirow[t]{2}{*}{ Primer } & \multirow{2}{*}{$\frac{\text { Annealing }}{\text { Temp }\left({ }^{\circ} \mathrm{C}\right)}$} & \multirow{2}{*}{$\frac{\text { Size }}{\text { (basepair) }}$} \\
\hline & & & \\
\hline $18 \mathrm{~S}$ & $\begin{array}{l}\text { F 5' GTAACCCGTTGAACCCCATT- 3' } \\
\text { R 5' CCATCCAATCGGTAGTAGCG 3' }\end{array}$ & 56 & 151 \\
\hline MLC- $2 \alpha$ & $\begin{array}{l}\text { F 5'-ATC TGC AAG GCA GAC CTG A-3' } \\
\text { R 5'-CAG GAG AAG CTG CTT GAA C-3' }\end{array}$ & 55 & 243 \\
\hline SERCA- $2 \alpha$ & $\begin{array}{l}\text { F 5'-TCT GGC ACT GCG GTG GCT AA-3' } \\
\text { R 5'-GGC CAT CTG TCA CCA GAT T-3' }\end{array}$ & 55 & 241 \\
\hline Desmin & $\begin{array}{l}\text { F 5'-TGTGGAGATTGCCACCTAC-3' } \\
\text { R 5'-CGTGTCTCGATGGTCTTGAT-3' }\end{array}$ & 64 & 185 \\
\hline Actinin & $\begin{array}{l}\text { F 5'-CCATGCTGCGACAGAAGGA-3' } \\
\text { R 5'-CCCTCCATCCAGTTGTTGA-3' }\end{array}$ & 64 & 337 \\
\hline
\end{tabular}

(Shandon cytospin 3, Thermo Scientific, Waltham, Mass., USA). Slides were air-dried overnight, fixed with acetone for $10 \mathrm{~min}$, incubated with mouse antibodies against human desmin (1:75, Sigma), $\alpha$-actinin (1:300, Sigma), troponin T (1:75, AbD Serotec, Oxford, UK) or MLC-2 $\alpha$ (1:100, Synaptic Systems, Göttingen, Germany) in PBS containing $1 \%$ BSA (PBS/BSA) for $1.5 \mathrm{~h}$ at room temperature, washed with PBS, and incubated with biotin-conjugated rabbit-antimouse antibodies (1:300, Dako Cytomation, Glostrup, Denmark) for $30 \mathrm{~min}$. After being washed in PBS, the slides were incubated with streptavidin-biotin complex/ horseradish peroxidase (sABC/HRP; 1:200, Dako) for $1 \mathrm{~h}$. Staining was visualized by using 3-amino-9-ethylcarbazole (AEC; Zymed AEC kit, Invitrogen). Finally, the cells were counterstained with hematoxylin and covered. Control slides were incubated with PBS instead of the primary antibody and showed no positive staining. All cytospin slides were scored blindly for the percentage of AEC positive cells; 100 cells were scored per slide.

\section{Statistics}

Statistics were performed with the SPSS statistics program (windows version 9.0) and Graphpad Prism (version 4).
The Repeated Measures method was used if values were obtained for all samples. Otherwise, an analysis of variance (ANOVA) was used if scores were distributed normally; if not or if $n$ was too small, a Kruskall-Wallis test was used for analysis. A $P$-value smaller than 0.05 was considered to be statistically significant. Values are given as mean $\pm \mathrm{SE}$.

\section{Results}

To investigate the effect of ECM proteins on cardiomyocyte differentiation, ASCs were cultured in fibronectin- or laminin-coated wells or in uncoated wells, with or without treatment with 5-aza-2-deoxycytidine. Before stimulation, ASCs displayed a fibroblast morphology, as previously described (Fig. 1a; Rangappa et al. 2003; Gaustad et al. 2004). After stimulation, the morphology of the cells changed. At 2 weeks, cells became larger and more elongated. Further, we found smaller numbers of ASCs in the wells that were treated with5-aza-2-deoxycitidine, suggesting a reduction of proliferation capacity (not shown). From 3 weeks after stimulation, multinucleated cells and ball-like figures were present in the wells containing 5-aza-2-deoxycitidine-stimulated cells, especial-
Fig. 1 Morphology of cells after treatment with 5-aza-2deoxycytidine. a Untreated cells on uncoated culture wells. ASCs display fibroblast morphology. b Cells treated with 5-aza-2deoxycytidine are elongated (arrow I) or occur in ball-like figures (arrow II). Note the low cell number
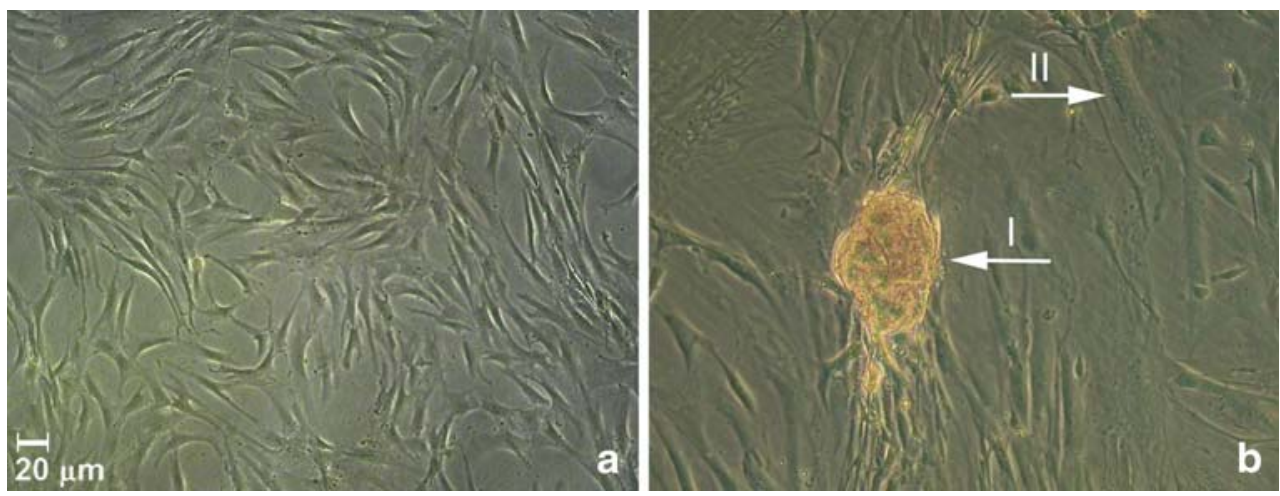
ly in the laminin-coated wells (Fig. 1b). mRNA expression of cardiac markers was studied by using RT-PCR. The control consisted of cells that were cultured on uncoated culture wells and not treated with 5-aza-2-deoxycitidine. In untreated cells, we could not detect any differences in SERCA- $2 \alpha$ and MLC- $2 \alpha$ mRNA expression between uncoated wells and wells coated with fibronectin or laminin, both after 1 and 5 weeks of culture (not shown). However, 1 week after treatment with 5-aza-2-deoxyciti- dine, mRNA expression of the early cardiac marker MLC$2 \alpha$ (Kubalak et al. 1994) was increased over 10-fold when compared with untreated cells (Fig. $2 \mathrm{a}, n=7, P<0.05$ ). This increase, however, was independent of coating. At 5 weeks after treatment, the expression of MLC- $2 \alpha$ mRNA was no longer found to be significantly increased when compared with untreated cells. mRNA expression for $\alpha$-actinin was not significantly different between the different timepoints (Fig. 2b). Desmin mRNA expression did not differ between
Fig. 2 Relative mRNA expression of cardiac markers in ASCs grown on uncoated culture wells $(-)$ or on wells coated with laminin (lam) or fibronectin (fib) and either untreated $(-)$ or treated $(+)$ with 5-aza-2deoxycytidine. Results are compared with untreated cells cultured on uncoated culture wells (error bars SEM).

a Relative mRNA expression of myosin light chain- $2 \alpha$ (MLC$2 \alpha ; n=7, * P<0.05, * * P<0.01$; Repeated Measures). b Relative mRNA expression of $\alpha$-actinin $(n=5)$. c Relative mRNA expression of desmin $(n=5)$. d Relative mRNA expression of SERCA- $2 \alpha(n=7, * P<0.05$, Repeated Measures)

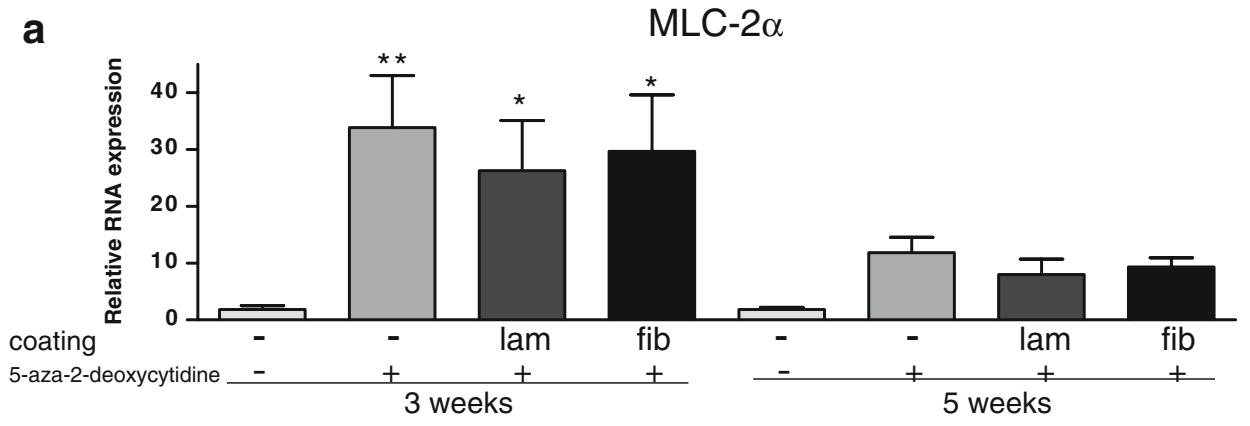

b
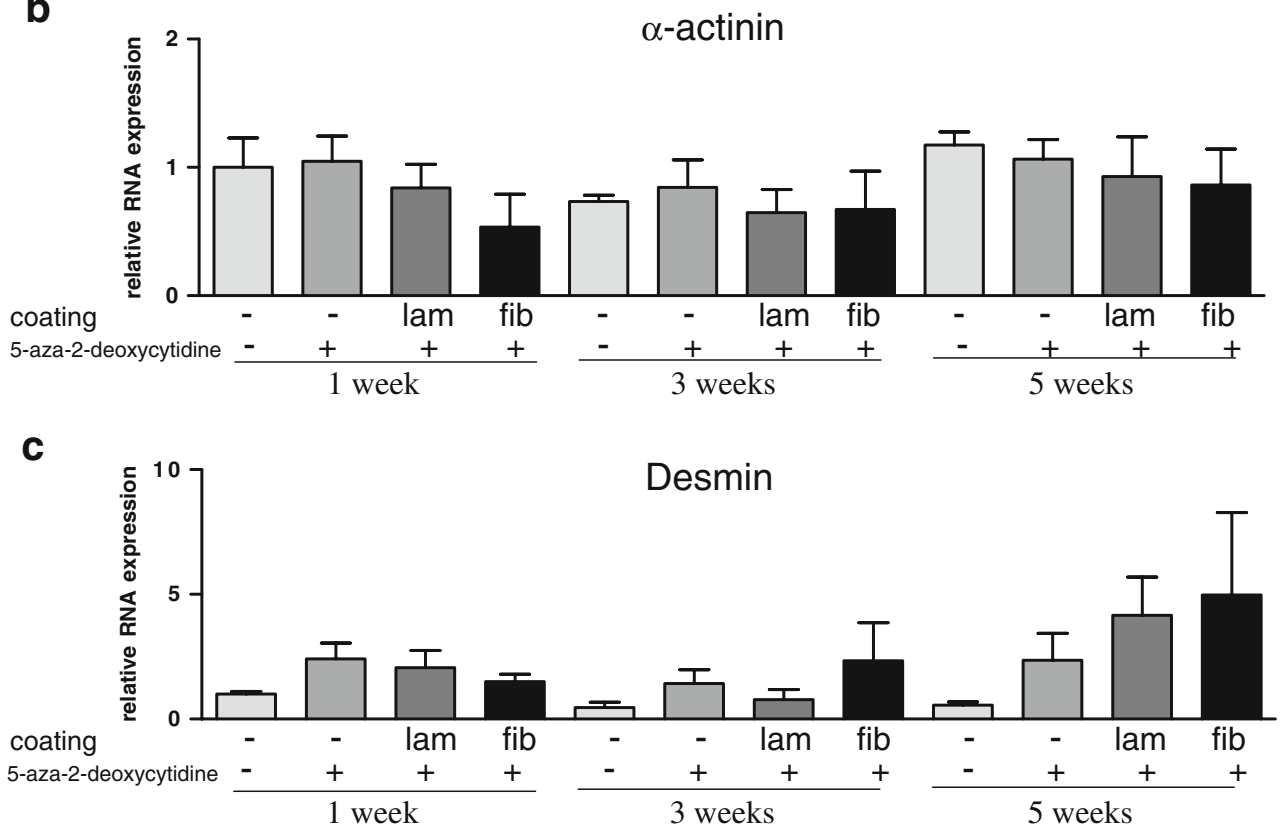

d

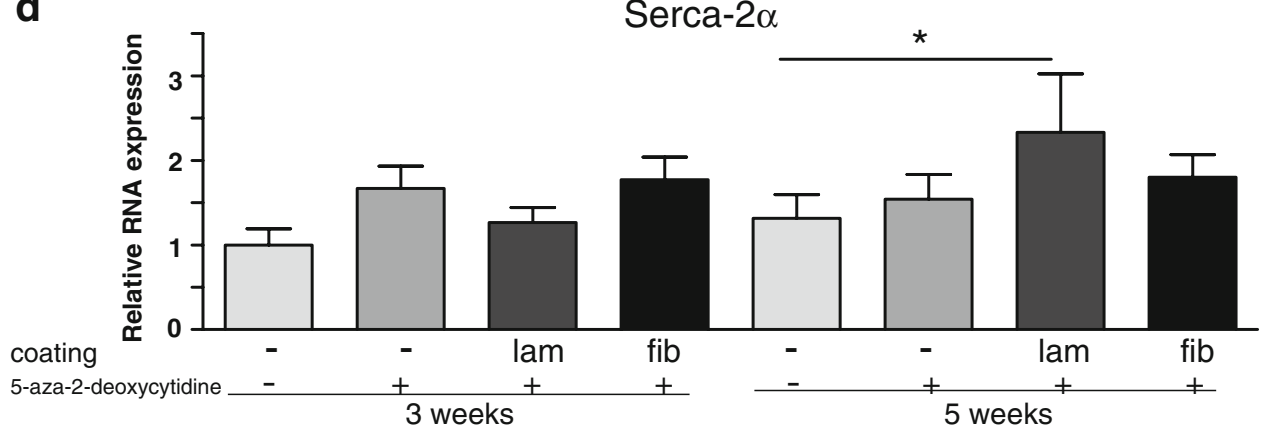


1 and 3 weeks, independent of coating. However, a clear trend was visible showing an increased expression of desmin mRNA expression at 5 weeks in stimulated cells, especially in the cells in coated culture wells (Fig. 2c, $P=$ 0.10 for laminin and fibronectin, compared with untreated cells after 5 weeks, $n=5$ ).

mRNA expression of the late differentiation marker cardiac SERCA2 $\alpha$ (Fijnvandraat et al. 2003) was not found to be significantly increased at 1 week after treatment with 5-aza-2-deoxycytidine. After 5 weeks, however, a significant increase of SERCA- $2 \alpha$ expression was found in treated cells that were cultured on laminin (Fig. $2 \mathrm{~d}, n=7$, $P<0.05)$. This increase was not found when cells were cultured in uncoated culture wells or on fibronectin.

To exclude that stimulation with 5-aza-2-deoxycitidine also triggered the differentiation of ASC towards other lineages, we also tested our samples for markers for osteogenic and chondrogenic lineages at 5 weeks after treatment, as described previously (Jurgens et al. 2008). No expression of the chondrogenic marker collagen type $2 \mathrm{~b}$ was found in any of the samples. Some expression of the chondrogenic marker aggrecan was found; however, this amount was too low to quantify. A low expression of the osteogenic markers osteopontin and collagen type 1A were found but no differences were found between untreated and treated cells suggesting that we had not induced differentiation into lineages other than the cardiac lineage by using 5-aza-2-deoxycitidine (not shown).

These results suggested that fibronectin and laminin had no additional affect on mRNA expression of cardiac markers during early differentiation, whereas the adherence of ASCs to laminin significantly improved late differentiation towards cardiomyocytes.

To exclude a putative effect of a lower concentration of fibronectin on differentiation, we also tested fibronectin at a single dose of $0.12 \mu \mathrm{g} / \mathrm{cm}$. This did not induce cardiac differentiation (not shown).

After studying mRNA expression, we next examined the protein expression of the cardiac markers MLC- $2 \alpha, \alpha-$ actinin, desmin and troponin $\mathrm{T}$ at 1,3 and 5 weeks after treatment. No protein expression could be detected for $\alpha$ actinin, desmin and troponin in cells at 1 week after treatment (not shown). Notably, when cells were not treated, no differences in the numbers of desmin- and actininpositive cells were found between uncoated wells and wells coated with fibronectin or laminin (not shown). In Fig. 3, representative examples of immunocytochemical staining of these proteins in cells derived from the same donor are shown; a considerable number of cells stained positively for $\alpha$-actinin, desmin, troponin T and MLC- $2 \alpha$ only in wells containing cells treated with 5-aza-2-deoxycytidine.

We next quantified the immunocytochemical staining. We found that, at 1 week after treatment with 5-aza-2- deoxycitidine, significantly more cells were positive for MLC- $2 \alpha$, when compared with untreated cells, but only in the wells containing treated cells cultured on laminin (Fig. 4a; $20 \pm 4 \%$ in untreated cells versus $51 \pm 9 \%$ in laminin-coated wells, $P<0.01)$. The percentage of MLC$2 \alpha$-positive cells on the laminin-coated wells was also significantly higher when compared with the 5-aza-2deoxycitidine-treated cells on uncoated culture wells (uncoated $26 \pm 7 \%$ versus laminin $51 \pm 9 \%, P<0.05$ ). After 3 weeks, no differences were found between the treated cells on the laminin-coated culture wells and on the uncoated culture wells. However, the percentage of MLC$2 \alpha$-positive cells was significantly lower in treated cells on fibronectin-coated culture wells than on uncoated culture wells (uncoated $52 \pm 2 \%$ versus $27 \pm 2 \%, P<0.01$ ). After 5 weeks, again only the wells coated with laminin contained a significantly higher number of MLC- $2 \alpha-$ positive cells, when compared with untreated cells (untreated $30 \pm 4 \%$ versus laminin $46 \pm 7 \%, P<0.05$ ). These results suggest a positive effect of laminin coating on MLC- $2 \alpha$ expression in ASCs.

We further found that, at 3 weeks after treatment, cytospin slides showed an increased number of treated cells staining positively for the intermediate marker $\alpha$ actinin when compared with untreated cells (Fig. 4b). However, this number was only significantly increased when ASCs were cultured in uncoated wells $(67 \pm 12 \%$ versus $5 \pm 2 \%, P<0.05)$. Percentages of positive cells on fibronectin- and laminin-coated culture wells were, respectively, $21 \pm 8 \%$ and $28 \pm 11 \%$ ( $P=0.16$ and $P=0.20$, respectively, compared with untreated). After 5 weeks, however, the percentage of $\alpha$-actinin positive cells in the uncoated culture wells was no longer significantly increased when compared with untreated cells and was similar to the percentage of positive cells in the wells coated with laminin and fibronectin (uncoated: $29 \pm 20 \%$, laminin-coated: $28 \pm$ $13 \%$, fibronectin-coated: $26 \pm 10 \%$ ).

Moreover, an increased number of desmin-positive cells (late marker) was found at 3 weeks after treatment (Fig. 4c). However, once again, this increase was only significant when cells were cultured in uncoated wells $(74 \pm 12 \%$ versus $5 \pm 1 \%, P<0.05)$. Percentage of positive cells in fibronectin- and laminin-coated culture wells were, respectively, $44 \pm 15 \%$ and $42 \pm 16 \% \quad(P=0.11$ and $P=0.16$, respectively). By 5 weeks after treatment, the percentage of desmin-positive cells cultured on uncoated and fibronectincoated culture wells decreased, but not significantly, when compared with that at 3 weeks (fibronectin-coated: $44 \pm 15 \%$ to $9 \pm 7 \%, P=0.07$; uncoated: $74 \pm 12 \%$ to $34 \pm 17 \%, P=$ $0.17)$. In contrast, when cells were cultured on laminin, the number of desmin-positive cells increased, but not significantly, compared with that at 3 weeks. More importantly, in these laminin-coated culture wells, the number of desmin- 
Fig. 3 Immunocytochemical analysis of the expression (red) of $\alpha$-actinin (a-c, 3 weeks), desmin (d-f, 5 weeks), Troponin $\mathrm{T}$ (g-i, 3 weeks) and MLC-2a $(\mathbf{j}-\mathbf{l}, 5$ weeks) in cells with and without treatment with 5 -aza2-deoxycitidine. a, d, g, j Untreated cells on uncoated culture wells (arrow I nuclei counterstained blue). $\mathbf{b}, \mathbf{e}, \mathbf{h}, \mathbf{k}$ Treated cells on uncoated culture wells (arrow II positive red staining for $\alpha$-actinin). c, $\mathbf{f}$, i, I Treated cells cultured on laminin-coated culture wells
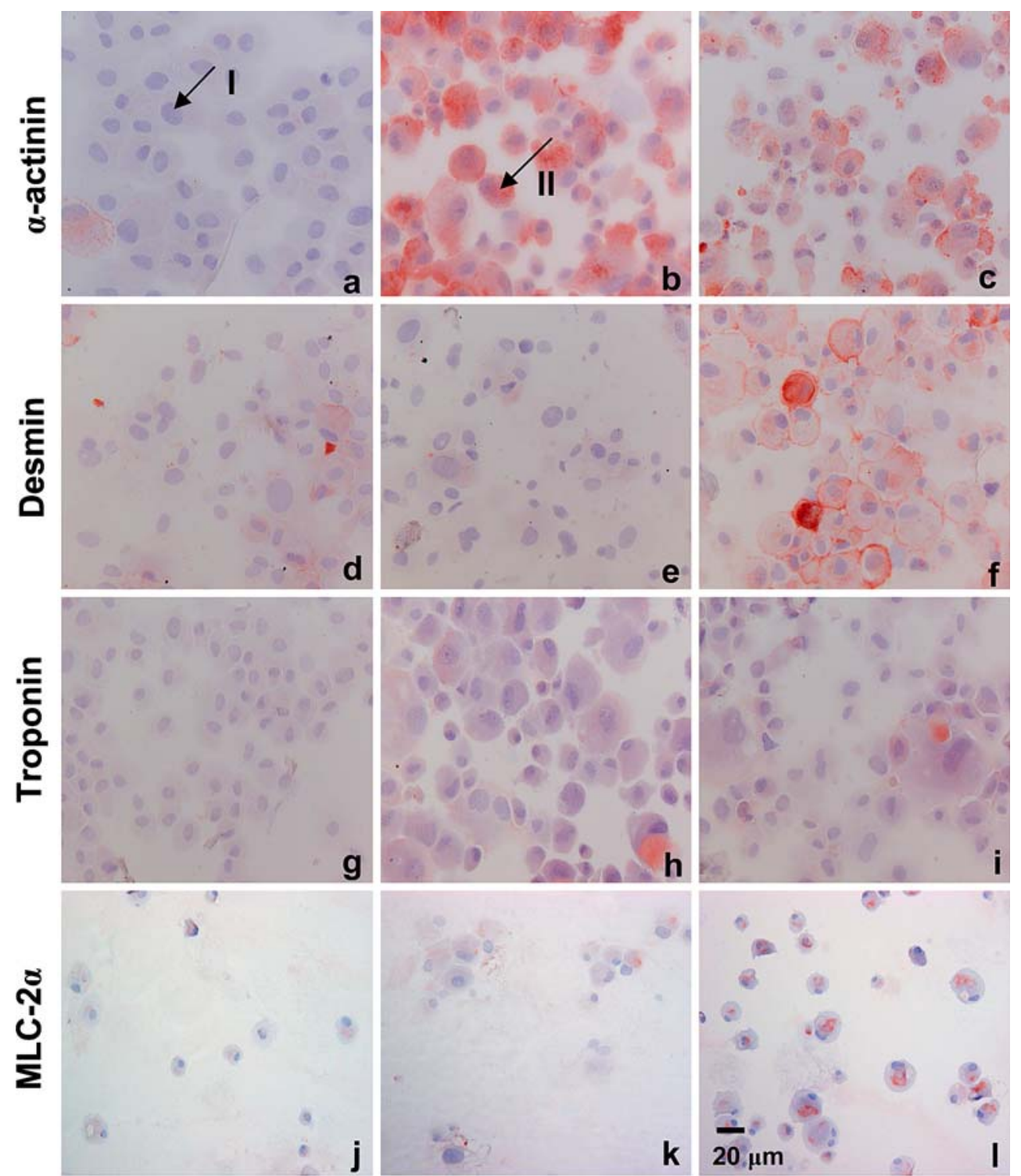

Uncoated
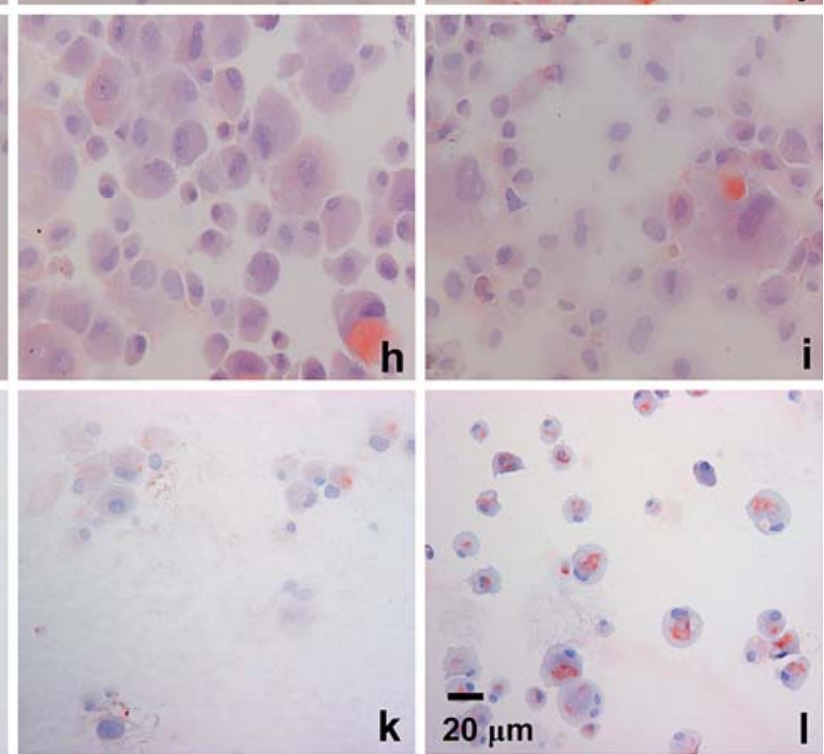

Uncoated

5-Azacytidine - positive cells was significantly increased compared with untreated cells $(61 \pm 12 \%$ versus $3 \pm 1 \%, P<0.05)$.

Finally, we also quantified troponin $\mathrm{T}$ protein expression (Fig. $4 \mathrm{~d}, n=3$ ). We found that, after 3 and 5 weeks, the percentage of positive cells was low in untreated cells $(2 \%$ and $1 \%$, respectively). In contrast, all wells containing treated cells showed higher numbers $(17 \%-32 \%)$ of troponin-T-positive cells, independent of coating; the highest percentages of positive cells were found in the uncoated wells at 3 and 5 weeks and in the laminin-coated culture wells at 3 weeks. These findings, however, were not statistically significant.

Thus, at the protein level, differentiation towards cardiomyocytes was also only found to be significantly increased in cells treated with 5-aza-2-deoxycytidine and cultured on laminin, especially with regard to late differentiation.

\section{Discussion}

We hypothesized that the attachment of ASCs to ECM molecules that are normally present in the healthy heart and that become upregulated after infarction would increase stem cell differentiation towards cardiomyocytes. Therefore, we have studied the effect of laminin and fibronectin on the differentiation of ASCs in vitro. We have found that a high percentage of human ASCs can differentiate towards cardiomyocytes, as shown at the mRNA level (MLC- $2 \alpha$, 
Fig. 4 Number of ASCs showing protein expression for cardiac markers after growth on uncoated culture wells $(-)$ or on wells coated with laminin (lam) or fibronectin $(f i b)$ and either untreated $(-)$ or treated $(+)$ with 5-aza-2-deoxycytidine. Results are expressed as percentage of positive cells and are compared with untreated cells (error bars SEM). a Myosin light chain- $2 \alpha$ $(M L C-2 \alpha)$ expression in ASCs $(n=5, * P<0.05, * * P<0.01$, ANOVA). b $\alpha$-Actinin expression in ASCs $(n=7, * P<0.05$, Repeated Measures). c Desmin expression in ASCs $(n=7$, ${ }^{*} P<0.05,{ }^{*} P<0.01$, Repeated Measures). d Troponin T expression in ASCs $(n=3$, Repeated Measures)
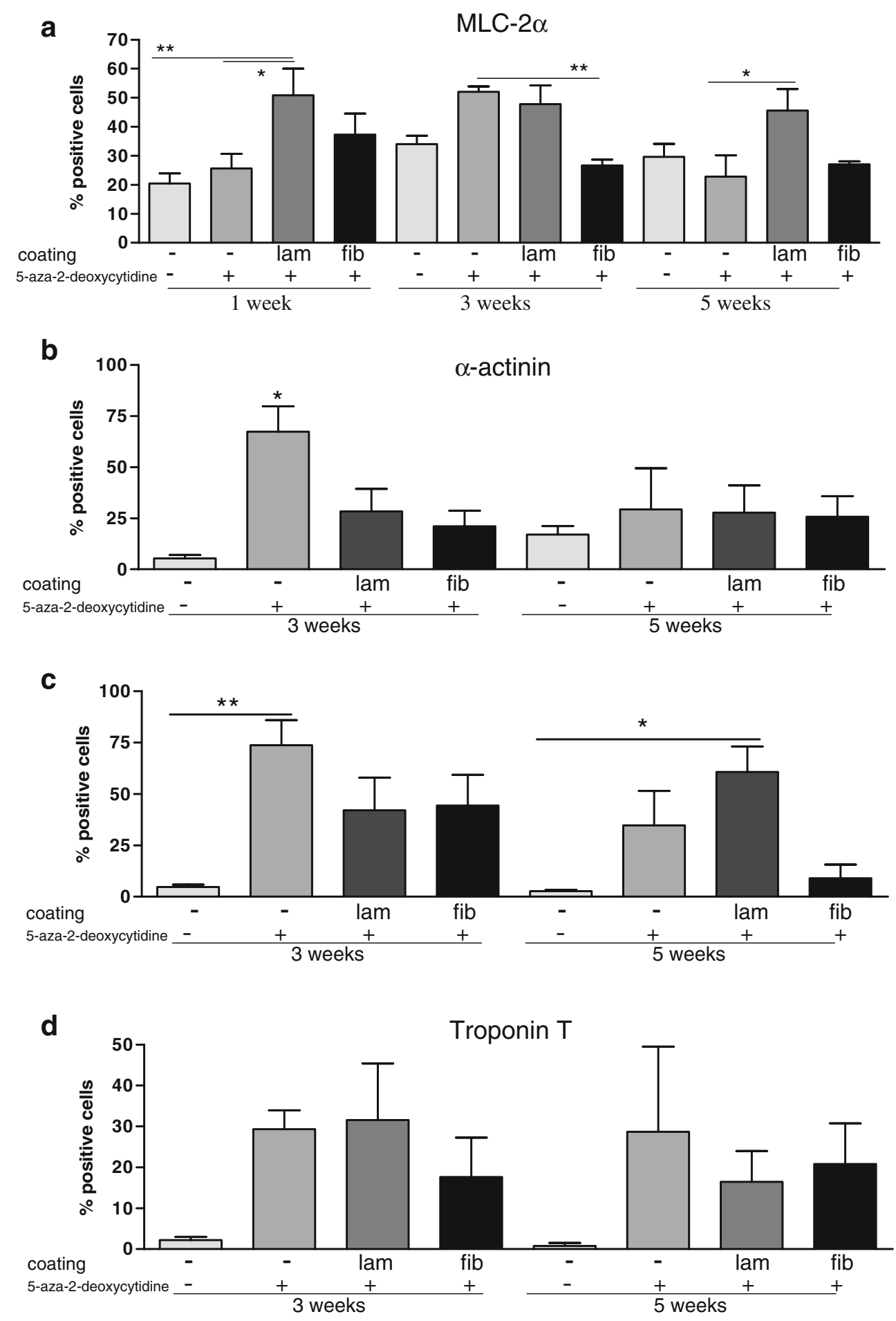

SERCA) and at the protein level (MLC- $2 \alpha, \alpha$-actinin, desmin, troponin $\mathrm{T}$ ), and that the ECM molecule laminin, but not fibronectin, plays a role in the differentiation of ASCs towards cardiomyocytes, especially during late differentiation.

Although some studies have previously described the differentiation of human ASCs towards cardiomyocytes (Bai et al. 2007; Song et al. 2007), this is the first time, to the best of our knowledge, that such a large number of human ASCs has been shown to differentiate along this route. Notably, we have demonstrated this effect in cells derived from several donors. Only Gaustad et al. (2004) have described the differentiation of human ASCs at levels comparable with ours; however they only studied ASCs derived from one patient. Our results in cells at 3 weeks 
after stimulation and grown on uncoated culture plates are similar to the data of Gaustad et al. (2004) who have shown $\alpha$-actinin expression in $81 \%$ (our study $67 \%$ ) and desmin expression in $25 \%$ (our study $74 \%$ ) of their cells. Furthermore, we have found an additional effect of culturing the cells on laminin, since the percentage of desmin-positive cells in uncoated culture wells decreased again after 5 weeks (35\%), whereas the percentage of desmin-positive cells in laminin-coated culture wells increased up to $61 \%$.

A major difference from the study of Gaustad et al. (2004) is that they permeabilized their ASCs and subjected them to rat cardiomyocyt extracts to achieve cardiomyocyte differentiation. Instead, we have used 2-deoxy-5-azacytidin, a demethylating agent that can be employed to prime cells before transplantation in vivo (Zhang et al. 2007; Burlacu 2006) and that is thus possibly more suitable for clinical use. Such a priming of stem cells in vitro before transplantation might be important, since theoretically this would prevent the spontaneous differentiation of stem cells into undesired lineages (Heng et al. 2004).

The positive effect of laminin on late stem cell differentiation might be caused by a real increase of differentiation attributable to laminin, although we cannot exclude that the attachment to laminin prevents the cells from dedifferentiation because, in the uncoated culture wells, both the percentages of $\alpha$-actinin- and desminpositive cells decreases between 3 and 5 weeks after treatment. However, since an increase of desmin-positive cells occurs, albeit not significantly, between 3 and 5 weeks in the laminin-coated culture wells, the positive effect of laminin is probably caused not only by the prevention of dedifferentiation, but also by a real increase in the number of cells that have differentiated during this period.

Although previous studies have suggested that the presence of the ECM that is normally present in the heart plays an important role in stem cell differentiation towards cardiomyocytes (Baharvand et al. 2005), this is, to the best of our knowledge, the first time that a positive effect of laminin attachment on stem cell differentiation towards cardiomyocytes has been described. Laminins are heterotrimers of large polypeptides (Kuang et al. 1998). In contrast to many matrix components that are ubiquitous in their distribution in the developing embryo, laminin is localized only in the basement membranes (Foster et al. 1987). This restricted distribution of laminin suggests a specific role for laminin in cell attachment, spreading and differentiation in embryogenesis. Indeed, laminin has been described to attach to myocardial cells as the principle adhesive molecule for the maintenance of architecture and differentiation in the embryo (Kim et al. 1999).

Several studies have described an effect of laminin on myogenesis. For example, Foster et al. (1987) have found that a laminin substrate promotes myogenesis in rat skeletal muscle cultures and Hilenski et al. (1992) have reported that laminin influences cytoskeletal and myofibrillar organization in vitro in neonatal rat cardiac myocytes. Further, mutations in the genes coding for the alpha-2 chain of two laminin isoforms have been shown to cause a severe form of congenital muscular dystrophy in humans and mice (Kuang et al. 1998).

Thus, laminin is known to play a role in regulating the differentiated phenotype of cells. Further, a large number of integrins have been described to interact with laminins (Thorsteinsdottir et al. 1999). In addition to their ability to link cells to their extracellular environment, integrins possess cytoplasmic domains that function in cellular signalling via their ability to associate with and activate signal transduction pathways (Kuang et al. 1998; Belkin and Stepp 2000). The interaction between integrins and laminins therefore can lead to many developmentally relevant processes, such as cell differentiation (Thorsteinsdottir et al. 1999).

In this study, we have found an effect of laminin on ASC differentiation, but no significant effect has been seen for fibronectin on ASC differentiation towards cardiomyocytes. However, we have previously reported that fibronectin improves stem cell attachment and proliferation (van Dijk et al. 2008). Other studies have also described the positive effect of laminin and the negative effect of fibronectin on myoblast formation. For example, Vachon et al. (1996) suggest that laminin plays a role in myoblast adhesion and myotube formation, whereas fibronectin stimulates myoblast adhesion and proliferation but does not improve myogenic differentiation. Moreover, Thyberg and Hultgardh-Nilsson (1994) have shown that laminin retains freshly isolated rat aortic smooth muscle cells in a contractile phenotype in primary culture, whereas fibronectin does not have this effect.

In previous studies, we have demonstrated that fibronectin stimulates ASC attachment and now we have shown that laminin promotes ASC differentiation. Since both laminin and fibronectin are upregulated after MI, their described effects might thus enhance ASC differentiation towards cardiomyocytes for MI therapy by stem cells. We therefore suggest that stem cell therapy should be applied when both fibronectin deposition (12 h to 15 days after MI, unpublished data) and laminin deposition (from day 3 after MI; Morishita et al. 1996) are high, i.e. from 3 days after MI.

Several other studies have also investigated the best timeframe after MI for the application of stem cell therapy, both in animal models and with regard to human stem cell transplantation, by examining molecular events and stem cell retention at the site of infarction (Lu et al. 2004; Ma et al. 2005; Bermejo et al. 2006). These investigations suggest 
that stem cell therapy should be applied neither during the acute inflammation phase (within 1 day after infarction), nor after a period longer than 2 weeks when scar tissue has formed. This is in agreement with our suggestion that stem cell therapy should be applied at least 3 days after MI.

In summmary, we have shown, for the first time, that a high percentage of human ASCs can differentiate towards cardiomyocytes and that the attachment of these cells to laminin improves late ASC differentiation towards cardiomyocytes. To achieve a positive effect of the ECM molecules fibronectin and laminin on the retrieval and differentiation of stem cells for use in the heart after MI, stem cell therapy should be applied when the deposition of these ECM molecules is high in the heart, i.e. at least 3 days after MI.

Open Access This article is distributed under the terms of the Creative Commons Attribution Noncommercial License which permits any noncommercial use, distribution, and reproduction in any medium, provided the original author(s) and source are credited.

\section{References}

Baharvand H, Azarnia M, Parivar K, Ashtiani SK (2005) The effect of extracellular matrix on embryonic stem cell-derived cardiomyocytes. J Mol Cell Cardiol 38:495-503

Bai X, Pinkernell K, Song YH, Nabzdyk C, Reiser J, Alt E (2007) Genetically selected stem cells from human adipose tissue express cardiac markers. Biochem Biophys Res Commun 353:665-671

Belkin AM, Stepp MA (2000) Integrins as receptors for laminins. Microsc Res Tech 51:280-301

Bermejo J, Segovia J, Alfonso F (2006) Summary of the clinical studies reported in the scientific session of the American Heart Association 2005 (Dallas, Texas, USA, 13-16 November 2005). Rev Esp Cardiol 59:143-153

Burlacu A (2006) Can 5-azacytidine convert the adult stem cells into cardiomyocytes? A brief overview. Arch Physiol Biochem 112:260-264

Chastain SR, Kundu AK, Dhar S, Calvert JW, Putnam AJ (2006) Adhesion of mesenchymal stem cells to polymer scaffolds occurs via distinct ECM ligands and controls their osteogenic differentiation. J Biomed Mater Res [A] 78:73-85

Dijk A van, Niessen HW, Ursem W, Twisk JW, Visser FC, Milligen FJ van (2008) Accumulation of fibronectin in the heart after myocardial infarction: a putative stimulator of adhesion and proliferation of adipose-derived stem cells. Cell Tissue Res 332:289-298

Fijnvandraat AC, Ginneken AC van, Boer PA de, Ruijter JM, Christoffels VM, Moorman AF, Lekanne Deprez RH (2003) Cardiomyocytes derived from embryonic stem cells resemble cardiomyocytes of the embryonic heart tube. Cardiovasc Res 58:399-409

Foster RF, Thompson JM, Kaufman SJ (1987) A laminin substrate promotes myogenesis in rat skeletal muscle cultures: analysis of replication and development using antidesmin and anti-BrdUrd monoclonal antibodies. Dev Biol 122:11-20

Froen JF, Larsen TH (1995) Fibronectin penetration into heart myocytes subjected to experimental ischemia by coronary artery ligation. Acta Anat (Basel) 152:119-126
Gaustad KG, Boquest AC, Anderson BE, Gerdes AM, Collas P (2004) Differentiation of human adipose tissue stem cells using extracts of rat cardiomyocytes. Biochem Biophys Res Commun 314:420 427

Hashimoto J, Kariya Y, Miyazaki K (2006) Regulation of proliferation and chondrogenic differentiation of human mesenchymal stem cells by laminin-5 (laminin-332). Stem Cells 24:2346-2354

Heng BC, Cao T, Haider HK, Wang DZ, Sim EK, Ng SC (2004) An overview and synopsis of techniques for directing stem cell differentiation in vitro. Cell Tissue Res 315:291-303

Hilenski LL, Ma XH, Vinson N, Terracio L, Borg TK (1992) The role of beta 1 integrin in spreading and myofibrillogenesis in neonatal rat cardiomyocytes in vitro. Cell Motil Cytoskeleton 21:87-100

Jurgens WJ, Oedayrajsingh-Varma MJ, Helder MN, Zandiehdoulabi B, Schouten TE, Kuik DJ, Ritt MJ, Milligen FJ van (2008) Effect of tissue-harvesting site on yield of stem cells derived from adipose tissue: implications for cell-based therapies. Cell Tissue Res 332:415-426

Kim H, Yoon CS, Kim H, Rah B (1999) Expression of extracellular matrix components fibronectin and laminin in the human fetal heart. Cell Struct Funct 24:19-26

Knowlton AA, Connelly CM, Romo GM, Mamuya W, Apstein CS, Brecher P (1992) Rapid expression of fibronectin in the rabbit heart after myocardial infarction with and without reperfusion. J Clin Invest 89:1060-1068

Kuang W, Xu H, Vachon PH, Engvall E (1998) Disruption of the lama2 gene in embryonic stem cells: laminin alpha 2 is necessary for sustenance of mature muscle cells. Exp Cell Res 241:117-125

Kubalak SW, Miller-Hance WC, O'Brien TX, Dyson E, Chien KR (1994) Chamber specification of atrial myosin light chain-2 expression precedes septation during murine cardiogenesis. J Biol Chem 269:16961-16970

Lee RJ, Fang Q, Davol PA, Gu Y, Sievers RE, Grabert RC, Gall JM, Tsang E, Yee MS, Fok H, Huang NF, Padbury JF, Larrick JW, Lum LG (2007) Antibody targeting of stem cells to infarcted myocardium. Stem Cells 25:712-717

Lu L, Zhang JQ, Ramires FJ, Sun Y (2004) Molecular and cellular events at the site of myocardial infarction: from the perspective of rebuilding myocardial tissue. Biochem Biophys Res Commun 320:907-913

Ma J, Ge J, Zhang S, Sun A, Shen J, Chen L, Wang K, Zou Y (2005) Time course of myocardial stromal cell-derived factor 1 expression and beneficial effects of intravenously administered bone marrow stem cells in rats with experimental myocardial infarction. Basic Res Cardiol 100:217-223

Malek S, Kaplan E, Wang JF, Ke Q, Rana JS, Chen Y, Rahim BG, Li M, Huang Q, Xiao YF, Verheugt FW, Morgan JP, Min JY (2006) Successful implantation of intravenously administered stem cells correlates with severity of inflammation in murine myocarditis. Pflugers Arch 452:268-275

Morishita N, Kusachi S, Yamasaki S, Kondo J, Tsuji T (1996) Sequential changes in laminin and type IV collagen in the infarct zone-immunohistochemical study in rat myocardial infarction. Jpn Circ J 60:108-114

Oedayrajsingh-Varma MJ, Ham SM van, Knippenberg M, Helder MN, Klein-Nulend J, Schouten TE, Ritt MJ, Milligen FJ van (2006) Adipose tissue-derived mesenchymal stem cell yield and growth characteristics are affected by the tissue-harvesting procedure. Cytotherapy 8:166-177

Orlic D, Kajstura J, Chimenti S, Limana F, Jakoniuk I, Quaini F, Nadal-Ginard B, Bodine DM, Leri A, Anversa P (2001) Mobilized bone marrow cells repair the infarcted heart, improving function and survival. Proc Natl Acad Sci USA 98:1034410349

Planat-Benard V, Menard C, Andre M, Puceat M, Perez A, GarciaVerdugo JM, Penicaud L, Casteilla L (2004) Spontaneous 
cardiomyocyte differentiation from adipose tissue stroma cells. Circ Res 94:223-229

Rangappa S, Fen C, Lee EH, Bongso A, Sim EK (2003) Transformation of adult mesenchymal stem cells isolated from the fatty tissue into cardiomyocytes. Ann Thorac Surg 75:775-779

Salasznyk RM, Williams WA, Boskey A, Batorsky A, Plopper GE (2004) Adhesion to vitronectin and collagen I promotes osteogenic differentiation of human mesenchymal stem cells. J Biomed Biotechnol 2004:24-34

Smits AM, Vliet P van, Hassink RJ, Goumans MJ, Doevendans PA (2005) The role of stem cells in cardiac regeneration. J Cell Mol Med 9:25-36

Song YH, Gehmert S, Sadat S, Pinkernell K, Bai X, Matthias N, Alt E (2007) VEGF is critical for spontaneous differentiation of stem cells into cardiomyocytes. Biochem Biophys Res Commun 354:999-1003

Strauer BE, Brehm M, Zeus T, Kostering M, Hernandez A, Sorg RV, Kogler G, Wernet P (2002) Repair of infarcted myocardium by autologous intracoronary mononuclear bone marrow cell transplantation in humans. Circulation 106:1913-1918

Strem BM, Zhu M, Alfonso Z, Daniels EJ, Schreiber R, Beygui R, MacLellan WR, Hedrick MH, Fraser JK (2005) Expression of cardiomyocytic markers on adipose tissue-derived cells in a murine model of acute myocardial injury. Cytotherapy 7:282-291
Thorsteinsdottir S, Roelen BA, Goumans MJ, Ward-van Oostwaard D, Gaspar AC, Mummery CL (1999) Expression of the alpha 6A integrin splice variant in developing mouse embryonic stem cell aggregates and correlation with cardiac muscle differentiation. Differentiation 64:173-184

Thyberg J, Hultgardh-Nilsson A (1994) Fibronectin and the basement membrane components laminin and collagen type IV influence the phenotypic properties of subcultured rat aortic smooth muscle cells differently. Cell Tissue Res 276:263-271

Vachon PH, Loechel F, Xu H, Wewer UM, Engvall E (1996) Merosin and laminin in myogenesis; specific requirement for merosin in myotube stability and survival. J Cell Biol 134:1483-1497

Wang QD, Sjoquist PO (2006) Myocardial regeneration with stem cells: pharmacological possibilities for efficacy enhancement. Pharmacol Res 53:331-340

Wijelath ES, Rahman S, Murray J, Patel Y, Savidge G, Sobel M (2004) Fibronectin promotes VEGF-induced CD34 cell differentiation into endothelial cells. J Vasc Surg 39:655-660

Willems IE, Arends JW, Daemen MJ (1996) Tenascin and fibronectin expression in healing human myocardial scars. J Pathol 179:321-325

Zhang DZ, Gai LY, Liu HW, Jin QH, Huang JH, Zhu XY (2007) Transplantation of autologous adipose-derived stem cells ameliorates cardiac function in rabbits with myocardial infarction. Chin Med J (Engl) 120:300-307 